\title{
Broiler Walking Ability and Toe Asymmetry Under Harsh Rearing Conditions
}

\section{-Author(s)}

Baracho $\mathrm{MS}^{1 *}$

Näs̈s IA ${ }^{1}$

Bueno LGF

Nascimento GR

Moura DJ'

${ }^{1}$ Agricultural EngineeringCollege -UNICAMP, Brazil.

2 College of Animal Science - UNESP Dracena

${ }^{3}$ Graduate student in Agricultural EngineeringUNICAMP, Brazil.

\section{Mail Adress}

E-mail: martbaracho@yahoo.com.br

\section{-Keywords}

Asymmetry, welfare, poultry.

\section{ABSTRACT}

Morphological asymmetry has been described as a potential broiler welfare indicator, for interpreting the birds' ability to cope with the challenges that may affect its growth. The objective of this study was to evaluate the use of morphological asymmetry data to estimate broiler walking ability and welfare.dBroilers werefed diets supplemented or not with vitamin D. Toes were measured when birds were 42 and 49 days old using digital caliper.the left and right sides of the following four bilateral traits (tarsometatarsus length, outer toe length, mid toe length, and back toe length) were measured twice on intact alive birds by two different researcherh. Data from right and left sides were compared in the two treatments using the Student t-test, and Pearson's correlation was used to analyze the total asymmetry found as a result of the total sum of the differences in the measurements. Asymmetry data were comparedwith the total numberof leg lesions. Mid toe and tarsometatarsus asymmetry resultswere considered as actual fluctuating asymmetry, and presented normal distribution (Test of Kolmogorov-Smirnov, $p>0.05$ ). However, back toe and outer toe measurements were not normally distributed, as determined by the test of Kolmogorov-Smirnov ( $p<0.05)$, indicating anti-asymmetry; when comparing right with left limb,results were significantly different fron zero (t-Student, $p<0.05$ ) indicating directional fluctuating asymmetry. The welfare of broilers withwalking difficulty due to the presence of severe asymmetry in limbs is poor.

\section{INTRODUCTION}

Morphological asymmetry has been describedas a potential broiler welfare indicator for interpreting birds' ability to cope with the challenges that may affect their growth (Tuyttens, 2003; Broom, 2006; Knierim, 2007). Fluctuating asymmetry is defined as random deviations from perfect growth symmetry that is generally expected in certain body parts when morphological development is successfully controlled, and it is the result of both genetic factors and environmental conditions.

Leg deformities are a common and severe problem in the broiler industry, and it is suggestedthat it is related to breeding (Kestinet al., 1992; Boekker \& Koene, 2003), harsh rearing conditions (Gonzales \& Macari, 2000; Dawkins et al., 2004), and stocking density (Sorensen et al., 2000; Hall, 2001). Leg disorders may reduce walking ability to walk, resulting in unnatural biomechanical forces, leg lesions, and ultimately gait changes that often lead to behavioral restriction, and,therefore, a welfare concern (Kestinet al., 1999; Hall, 2001; Reiter \& Kutriz, 2001; Weary et al., 2006).

Lameness in broilers with poor gait scores has been extensivelystudied (McGeown et al., 1999; Danbury et al., 2000; Weary et al., 2006; Nääs 
et al., 2009). Some authors propose the use o feed additives (Rathet al., 1998) or the dietary addition of vitamin D (Edwards Jr., 1989, Whitehead et al., 2004; Waldenstedt, 2006; Leeson, 2007) to alleviate this condition.

Thisstudy aimedat evaluating the use of morphological asymmetry data to estimate broiler walking ability and welfare.

\section{MATERIALS AND METHODS}

The housing and experimental procedures reported herein were approved by the Institutional Animal Care and Use Committee (CEEA 1664-1) of the State University of Campinas, Brazil.

\section{Birds, housing and management}

Thirty birds were selected from a flock of 300 one-day-old Cobb $500^{\circledR}$ male chicks weighing 0.47 $\mathrm{kg} \pm 0.014$.s Chicks wer reared in siebroiler houses (experimental small-scale houses measuring 3.0 2.0 $\times 1.4 \mathrm{~m}$ ) located in an open area. Houses were built iEeastWwest directio,and open-sided with solid walls at the ends. Housed were equipped with yellow polypropylene $(170 \mu / \mathrm{mm})$ side curtains that could be opened when needed, and 50-mm deep wood-shaving litter on the concrete floor. Wood shavings were regularly replaced to maintaindproper litter conditions throughout the experiment. A brooder was placed in one corner of each house to provide supplemental heat during the first weeks. Each housewas equipped with atube feeder and bell drinker. Fresh water was supplied a plastic water tank located at the south end of each house. Broilers were fed a starter diet (ME = $3,125 \mathrm{kcal} / \mathrm{kg}, 22 \% \mathrm{CP}$ ) during the first two weeks, a growe'diet (ME = 3,150 kcal $/ \mathrm{kg}, 20 \% \mathrm{CP}$ ) from 15 to $42 \mathrm{~d}$ of age, and a finisher diet (ME $=3,125 \mathrm{kcal} / \mathrm{kg}$, $20 \%$ CP) thereafter. Feed and water were offeredad libitum. The birds in the flockwere reared to 49 days old with a maximum flock density of $30 \mathrm{~kg} / \mathrm{m}^{2}$ during the study.

\section{Treatments}

Two treatments were applied. Birds in treatmentA (control) was fed a placebo $(0.2 \mathrm{~kg} / 1,000 \mathrm{~L}$ ), and those in treatmentB were fed 25-hydroxycholecalciferol (25$\left.\mathrm{OH}-\mathrm{D}_{3}\right)$ in a soluble form $(0.2 \mathrm{~kg} / 1000 \mathrm{~L}$, equivalent to $0.069 \mathrm{~kg} /$ ton of feed)diluted in the drinking water. Both groups were exposed during rearing to natural ventilation and weather conditions (temperature and relative humidity) as presented during the summer of 2008/09 in Campinas, Brazil $\left(47^{\circ} 03^{\prime}\right.$ W, $22^{\circ} 54^{\prime} \mathrm{S}$, $854 \mathrm{~d}$ altitudm). The local season average dry bulb temperature was $27.5^{\circ} \mathrm{C}$ with $83 \%$ relative humidity and SE prevailing wind.

\section{Experimental procedure}

Five birds from each housewere at randomselected daily, and their weights were recorded. Feed intake and water consumption were recordeddaily by weighing theamount offeredand the residues remaining both in the feeder and in the drinker. Ambient temperature, relative humidity, air velocity, and light intensity inside the houses were continuously recorded using a data logger placed in the center of the house at a height of $0.8 \mathrm{~m}$. Fifteen broilers were randomly removed from groups A and B (five from each house) at 28, 35, 42, and $49 \mathrm{~d}$ of age for locomotionevaluation. Locomotion ability was evaluated by scoring each bird according to the subjective gait scoring system (GS) suggested by Dawkins (2004). Ten consecutive steps given by the birdwere observed. The following scale was used: 0 for birds that walked 10 steps normally; 1 for birds that walked 10 steps with some difficulty, showing unbalanced walking; and 2 for birds that could not walk more than four steps, and sat afterwards. The GS was evaluated by a trained observer.

\section{Post-mortem examination and morpho- logical asymmetry measurements}

All birds were euthanized by cervical dislocation, and subsequently submitted to post-mortem examination. The following conditions were evaluated during the examination: physical abnormalities of the legs (FL), tibialdyschondroplasia (TD), valgus-varus deformities (VVD), angular bone deformities (ABD), spondylolisthesis (S), femoral head necrosis (FHN), curled toes $(\mathrm{CT})$, and ruptured gastrocnemius tendon (RGT).

Toe measurements were taken twice in 60 live birds by two distinct persons (Van Nuffelet al., 2007; Van Pouckeetal., 2007), using a digital caliper (to the nearest $0.01 \mathrm{~mm}$ ). The left and right sides of the following four bilateral traitswere measured:tarsometatarsallength; outer-toe length; mid-toe length and back-toe length.

\section{Data analysis}

Data were analyzed using one-way analysis of variance (ANOVA) at 95\% statistical significance level. Paired test was used to compare the results. Effects were considered significant atp $<0.05$ and, in some specified cases, at $p<0.10$. All analyses were performed using a statistical software program (Minitab, 2007). 
The total amount of differences than sum of all the differences determined in the measurements, and it was used to analyze asymmetry (Palmer \&Strobeck, 2003). The obtained asymmetry was comparedwith the total number of leg lesions observed.Right (R) and left ( $\mathrm{L}$ ) data were comparedbetween the two treatments using the Student'st-test and Pearson's correlation test. Kolmogorov-Smirnov's test was applied to test if data was normally distributed. All statistical analyses were carried out using the statistical software programMinitab ${ }^{\circledR}$ (2007).

\section{RESULTS AND DISCUSSION}

Table 1 and 2 show back toe, mid toe, outer toeand tarsometatarsus measurements, in $\mathrm{mm}$, of the left and right legs of 42- and 49-day-old broilers submitted to treatments A and B. Student's t-test showed differences between the right and left legs in all measurements in 42-d-old broilers submitted to treatment $A$, while no differences were found in treatment $B$ broilers.

Table 1 - Mean, standard deviation (SD)of back toe, outer toe, mid toe and tarsometatarsus length (mm)and Student t-test of comparing the right and left legs of 42-d-old broilers

\begin{tabular}{|c|c|c|c|c|}
\hline & Treatment & Leg & Mean \pm SD & $\mathbf{p}$-value \\
\hline \multirow{4}{*}{ Back toe } & \multirow{2}{*}{ A } & $\mathrm{R}$ & $16.7 \pm 1.1$ & \multirow{2}{*}{0.01 * } \\
\hline & & L & $17.7 \pm 0.9$ & \\
\hline & \multirow{2}{*}{ B } & $\mathrm{R}$ & $17.0 \pm 1.0$ & \multirow{2}{*}{0.06} \\
\hline & & L & $17.6 \pm 0.8$ & \\
\hline \multirow{4}{*}{ Outer toe } & \multirow{2}{*}{ A } & $\mathrm{R}$ & $20.9 \pm 1.1$ & \multirow{2}{*}{$0.03 *$} \\
\hline & & L & $21.5 \pm 1.0$ & \\
\hline & \multirow{2}{*}{ B } & $\mathrm{R}$ & $20.7 \pm 1.2$ & \multirow{2}{*}{0.06} \\
\hline & & L & $21.5 \pm 1.0$ & \\
\hline \multirow{4}{*}{ Mid toe } & \multirow{2}{*}{ A } & $\mathrm{R}$ & $20.8 \pm 0.9$ & \multirow{2}{*}{$0.03 *$} \\
\hline & & L & $21.3 \pm 0.8$ & \\
\hline & \multirow{2}{*}{ B } & $\mathrm{R}$ & $20.9 \pm 0.9$ & \multirow{2}{*}{0.60} \\
\hline & & L & $21.1 \pm 0.8$ & \\
\hline \multirow{4}{*}{ Tarsometatarsus } & \multirow{2}{*}{ A } & $\mathrm{R}$ & $60.8 \pm 1.8$ & \multirow{2}{*}{0.01 * } \\
\hline & & $\mathrm{L}$ & $59.3 \pm 1.0$ & \\
\hline & \multirow{2}{*}{ B } & $\mathrm{R}$ & $59.6 \pm 1.0$ & \multirow{2}{*}{0.76} \\
\hline & & L & $59.5 \pm 0.6$ & \\
\hline
\end{tabular}

* Significant $(p<0.05)$

Treatment A (control): broilersfed a placebo $(0.2 \mathrm{~kg} / 1000 \mathrm{~L})$

Treatment B broilers fed 25-hydroxycholecalciferol (25-OH-D3) in a soluble form $(0.2 \mathrm{~kg} / 1000 \mathrm{~L}$, equivalent to $0.069 \mathrm{~kg} /$ ton of feed).
Table 2 - Mean, standard deviation (SD) of back toe, outer toe, mid toe and tarsometatarsus length $(\mathrm{mm})$ and Student t-test of comparing the right and left legs of 49-d-old broilers.

\begin{tabular}{|c|c|c|c|c|}
\hline & Treatment & Leg & Average & $\mathrm{p}$-value \\
\hline \multirow{4}{*}{ Back toe } & \multirow{2}{*}{ A } & $R$ & $17.5 \pm 1.4$ & \multirow{2}{*}{0.90} \\
\hline & & L & $17.7 \pm 1.7$ & \\
\hline & \multirow{2}{*}{ B } & $R$ & $17.1 \pm 1.9$ & \multirow{2}{*}{0.34} \\
\hline & & $\mathrm{L}$ & $17.7 \pm 1.6$ & \\
\hline \multirow{4}{*}{ Outer toe } & \multirow{2}{*}{ A } & R & $21.3 \pm 1.5$ & \multirow{2}{*}{0.35} \\
\hline & & L & $21.8 \pm 1.8$ & \\
\hline & \multirow{2}{*}{ B } & $\mathrm{R}$ & $21.9 \pm 1.8$ & \multirow{2}{*}{0.55} \\
\hline & & $\mathrm{L}$ & $22.3 \pm 1.5$ & \\
\hline \multirow{4}{*}{ Mid toe } & \multirow{2}{*}{ A } & $R$ & $21.4 \pm 1.6$ & \multirow{2}{*}{0.26} \\
\hline & & L & $21.9 \pm 1.3$ & \\
\hline & \multirow{2}{*}{ B } & $\mathrm{R}$ & $21.9 \pm 1.6$ & \multirow{2}{*}{0.76} \\
\hline & & $\mathrm{L}$ & $22.1 \pm 1.4$ & \\
\hline \multirow{4}{*}{ Tarsometatarsus } & \multirow{2}{*}{ A } & $\mathrm{R}$ & $65.5 \pm 2.2$ & \multirow{2}{*}{0.33} \\
\hline & & L & $64.7 \pm 2.6$ & \\
\hline & \multirow{2}{*}{ B } & $R$ & $64.9 \pm 2.4$ & \multirow{2}{*}{0.71} \\
\hline & & L & $64.4 \pm 3.2$ & \\
\hline
\end{tabular}

Treatment A (control): broilers fed a placebo $(0.2 \mathrm{~kg} / 1000 \mathrm{~L})$

Treatment B broilers fed 25-hydroxycholecalciferol (25-OH-D3) in a soluble form $(0.2 \mathrm{~kg} / 1000 \mathrm{~L}$, equivalent to $0.069 \mathrm{~kg} /$ ton of feed)

At 42 days of age, back toe, outer toe, and mid toe measurements were not significantly different between treatments ( $p>0.05$; Table 3 ). Tarsometatarsus was significantly longer in 41-d-old broilers submitted to treatment $A(p<0.05)$, as shown in Table 1 . At 49 days of age, no significant difference was found between treatments (Table 3), possibly because the test did not use the same bird at both ages.

It is reported in literature that leg disorders are, in general, proportional to body weigh, and that younger birds (> 42d) are more sensitive to increase in body weight than older birds (Skinner et al., 1992; Kerstin et al., 2001). In the present experiment, birds were randomly selected for each age test, and the results showed that dietary supplementation with soluble $25-\mathrm{OH}-\mathrm{D}_{3}$ can prevent the occurrence of leg disorders. This may be associated to better skeletal structure due to a better utilization of nutrients for growth during the first days of life (Applegate \& Liburn, 2002). When ensuringaccess to vitamin $D$ to young poultry, there is correct bone metabolism and bone abnormalitiesare reduced (Edwards et al., 1992; Silva et al., 2001; Whitehead et al., 2004; Rennie\& Whitehead, 1996, Mitchell et al., 1997; Edwards, 1989, Zhang et al., 1997). According to Bruno et al. (2007), there is rapid bone development in broilers up to 28 days of age; however, in this present study, it was observed that 
Table 3 - Comparison of back toe, outer toe, mid toeand tarsometatarsus length in the treatments (42 and 49 days).

\begin{tabular}{|c|c|c|c|c|c|}
\hline & & Back toe & Outer toe & Mid toe & Tarsometatarsus \\
\hline Days of age & Treatment & & & & \\
\hline \multirow{3}{*}{42} & A & $17.1 \pm 1.2$ & $21.3 \pm 1.0$ & $21.0 \pm 1.0$ & $60.5 \pm 2.0$ \\
\hline & B & $17.3 \pm 0.9$ & $21.1 \pm 1.2$ & $21.0 \pm 0.8$ & $59.6 \pm 0.8$ \\
\hline & $p$-value & 0.40 & 0.64 & 0.87 & $0.02^{*}$ \\
\hline \multirow{3}{*}{49} & A & $17.6 \pm 1.5$ & $21.6 \pm 1.6$ & $21.7 \pm 1.4$ & $65.1 \pm 2.4$ \\
\hline & B & $17.4 \pm 1.7$ & $22.1 \pm 1.6$ & $22.1 \pm 1.5$ & $64.6 \pm 2.8$ \\
\hline & $p$ - value & 0.60 & 0.20 & 0.40 & 0.47 \\
\hline
\end{tabular}

*Significant $(p<0.05)$.

Treatment A (control): broilers fed a placebo $(0.2 \mathrm{~kg} / 1000 \mathrm{~L}$ )

Treatment B broilers fed 25-hydroxycholecalciferol $(25-\mathrm{OH}-\mathrm{D} 3)$ in a soluble form $(0.2 \mathrm{~kg} / 1000 \mathrm{~L}$, equivalent to $0.069 \mathrm{~kg} /$ ton of feed)

this development may continue. According Naas et al. (2009), broilers supplemented with vitamin $\mathrm{D}_{3}$ and showed significant differences in the highest vertical force between the right and the left leg at 28, 35 and 49 days of age, but no difference was foundwhen broiler were 42 days old.

In order to test possible asymmetry between the right (R) and left (L) limbs, measurements were submitted to Kolmogorov-Smirnov's normality test. Student'st-test was applied to verify if $R$ and $L$ values were significantly different from zero and represent an asymmetry (Table 4). Mid toe and tarsometatarsus asymmetry results were considered as actual fluctuating asymmetr, and presented normal distribution (Test of KolmogorovSmirnov, p > 0.05; Table 4).

Table 4 - Results of the Kolmogorov-Smirnov (K-S) test and Student's t-test

\begin{tabular}{|c|c|c|c|}
\hline & \multirow{2}{*}{$\frac{\mathrm{K}-\mathrm{S}}{\mathrm{p}-\text { value }}$} & \multicolumn{2}{|c|}{ Student's t-test } \\
\hline & & $\mathrm{t}$ & $p$ - value \\
\hline Back toe & $0.039 *$ & 3.87 & $0.001 *$ \\
\hline Outer toe & $0.048^{*}$ & 2.95 & $0.004^{*}$ \\
\hline Mid toe & $>0.15$ & 2.28 & $0.024^{*}$ \\
\hline Tarsometatarsus & $>0.15$ & 4.4 & $0.001 *$ \\
\hline \multicolumn{4}{|c|}{$\begin{array}{l}\text { * Significant non-normal distribution by Kolmogorov-Smirnov test }(p< \\
0.05) \text {. } \\
\text { Treatment A (control): broilers fed a placebo }(0.2 \mathrm{~kg} / 1000 \mathrm{~L}) \\
\text { Treatment B broilers fed } 25 \text {-hydroxycholecalciferol }(25-\mathrm{OH}-\mathrm{D} 3) \text { in a } \\
\text { soluble form }(0.2 \mathrm{~kg} / 1000 \mathrm{~L} \text {, equivalent to } 0.069 \mathrm{~kg} / \mathrm{ton} \text { of feed) }\end{array}$} \\
\hline
\end{tabular}

Kolmogorov-Smirnov's test results of back toe and outer toe measurements indicated that these data did not present normal distribution $(p<0.05)$, leading to symmetry. Also, $R$ and $L$ value were significantly different from zero (t-Student, $p<0.05)$. This directional fluctuating asymmetry is a tendency the limb has to be asymmetric in a specific direction (Ducheret al., 2005; Van Valen, 1962). In some cases, directional asymmetry (Graham et al. 1993; Møller 1994) and asymmetry (Mckenzie\& Clarke 1988; Leary \& Allendorf, 1989) may be used to estimate homeostasis. According to Bizeray et al. (2000), asymmetrical bone development is naturally compensated by asymmetric gait,causing future lameness. This has a negative impact on welfare, because it makes it difficult for the bird to reach feeders and drinkers, and ultimately causes pain (Weeks et al., 2000; Kestin et al., 2001, Manning et al., 2007).

No significant correlations were found betweenback toe, outer toe, mid toe and tarsometatarsus asymmetry with gait scordo the presence of leg or spinal column lesions in 42-d-old birds from both treatments(Table 5).At 49 days of age (Table 6), there wasno correlation between general asymmetry, gait score or and leg lesions in birds submitted to both treatments. However, there was a positive correlation $(p<0.05)$ between back toe and outer toe asymmetry with the presence of leg lesions (0.63 and 0.55, respectively; Table 6) in treatment A. Tarsometa tarsus asymmetry was positively correlated $(p<0.05)$ with gait score in treatment A (0.60; Table 6).

This positive correlation indicates a possible negative effect on production, because it may compromise broiler walking ability and well being (Dawkins et al., 2003; Knowles et al., 2008). These results may have been influenced by environmental conditions and flock density, particularly during the last weeks of rearing due to increasing body weight and high stress levels (Ravindranet al., 2006). Elkin (1978) states that leg abnormalities in broilers are related to organic disorders in bone development in which the physical properties of collagen are altered during growth, leading to weak legs and gait problems, with a consequent reduction in feed intake and productivity (Onyango et al.,2003). 
Table 5 - Pearson's correlation ( $p$-value) between back toe, outer toe, mid toe and tarsometatarsus asymmetry

\begin{tabular}{|c|c|c|c|c|c|}
\hline \multirow{2}{*}{ Treatment } & \multirow{2}{*}{ Occurrence } & \multicolumn{4}{|c|}{ Occurrence } \\
\hline & & Back toe & Outer toe & Mid toe & Tarsometatarsus \\
\hline \multirow{6}{*}{ A } & \multirow{2}{*}{ Gait score } & -0.20 & -0.25 & -0.52 & -0.05 \\
\hline & & $(0.48)$ & $(0.38)$ & $(0.05)$ & $(0.85)$ \\
\hline & \multirow{2}{*}{ Gait score } & -0.07 & 0.02 & -0.40 & -0.24 \\
\hline & & $(0.80)$ & $(0.95)$ & $(0.14)$ & (0.39) \\
\hline & \multirow{2}{*}{ Spine injury } & 0.02 & 0.08 & -0.20 & 0.13 \\
\hline & & $(0.93)$ & $(0.78)$ & $(0.50)$ & $(0.64)$ \\
\hline \multirow{6}{*}{ B } & \multirow{2}{*}{ Gait score } & -0.20 & 0.09 & -0.23 & -0.18 \\
\hline & & (0.96) & $(0.74)$ & $(0.41)$ & $(0.51)$ \\
\hline & \multirow{2}{*}{ Gait score } & 0.17 & 0.11 & 0.17 & 0.26 \\
\hline & & $(0.55)$ & $(0.70)$ & $(0.56)$ & $(0.34)$ \\
\hline & \multirow{2}{*}{ Spine injury } & 0.45 & 0.08 & 0.35 & -0.52 \\
\hline & & (0.09) & $(0.78)$ & $(0.20)$ & (0.05) \\
\hline
\end{tabular}

Treatment A (control): broilers fed a placebo $(0.2 \mathrm{~kg} / 1000 \mathrm{~L})$

Treatment B broilers fed 25-hydroxycholecalciferol (25-OH-D3) in a soluble form $(0.2 \mathrm{~kg} / 1000 \mathrm{~L}$, equivalent to $0.069 \mathrm{~kg} / \mathrm{ton}$ of feed).

\section{CONCLUSION}

The addition of vitamin $\mathrm{D}$ in the diet positively influenced the symmetry of right and left back toe, outer toe, and mid toe measurements. The tarsometatarsalasymmetry found in the present study was presented by broilers not supplemented with vitamin $D$ and was positively correlated with high gait score values, leading to poor welfare.

\section{ACKNOWLEDGMENTS}

The National Council for Scientific and Technological Development (CNPQ) and Foundation for Research at the State of São Paulo (FAPESP).

\section{REFERENCES}

Applegate TJ, Lilburn MS. Growth of the femur and tibia of a commercial broiler line. Poultry Science 2002;81:1289-1294.

Bizeray D, Leterrier C, Constantin P, Picard M, Faure JM. Early locomotorbehaviour in genetic stocks of chickens with different growth rates. Applied Animal Behaviour Science 2000;68:231-242.

Bokkers EAM, KoeneP. Behaviour of fast and slow growing broilers to 12 weeks of age and the physical consequences. Applied Animal Behaviour Science 2003; 81:59-72.

Broom DM. Behaviour and welfare in relation to pathology.Applied Animal Behaviour Science 2006;97:73-83.

Bruno LDG, Luquetti BC, Furlan RL, Macari M. Influence of early qualitative feed restriction and environmental temperature on long bone development of broiler chickens. Journal of Thermal Biology 2007;32:349-354.2007

Table 6 - Pearson's correlation ( $p$-value) between back toe, outer toe, mid toe and tarsometatarsus asymmetry

\begin{tabular}{|c|c|c|c|c|c|}
\hline \multirow{2}{*}{ Treatment } & \multirow{2}{*}{ Occurrence } & \multicolumn{4}{|c|}{ Occurrence } \\
\hline & & Back toe & Outer toe & Mid toe & Tarsometatarsus \\
\hline \multirow{6}{*}{$A$} & \multirow{2}{*}{ Gait score } & 0.48 & 0.29 & 0.23 & 0.60 \\
\hline & & $(0.07)$ & $(0.29)$ & $(0.41)$ & $(0.02 *)$ \\
\hline & \multirow{2}{*}{ Gait score } & 0.63 & 0.55 & 0.36 & 0.50 \\
\hline & & $(0.01 *)$ & $\left(0.04^{\star}\right)$ & $(0.19)$ & $(0.06)$ \\
\hline & \multirow{2}{*}{ Spine injury } & 0.26 & 0.16 & 0.40 & -0.07 \\
\hline & & $(0.35)$ & $(0.57)$ & $(0.14)$ & $(0.81)$ \\
\hline \multirow{6}{*}{ B } & \multirow{2}{*}{ Gait score } & 0.07 & -0.50 & -0.23 & -0.40 \\
\hline & & $(0.80)$ & $(0.06)$ & $(0.40)$ & $(0.14)$ \\
\hline & \multirow{2}{*}{ Gait score } & 0.26 & 0.03 & 0.21 & -0.05 \\
\hline & & $(0.35)$ & $(0.92)$ & $(0.46)$ & $(0.86)$ \\
\hline & \multirow{2}{*}{ Spine injury } & -0.28 & 0.05 & -0.04 & -0.27 \\
\hline & & (0.31) & $(0.86)$ & $(0.88)$ & (0.33) \\
\hline
\end{tabular}

* Significant $(p<0.05)$.

Treatment A (control): broilers fed a placebo $(0.2 \mathrm{~kg} / 1000 \mathrm{~L})$

Treatment B broilers fed 25-hydroxycholecalciferol (25-OH-D3) in a soluble form $(0.2 \mathrm{~kg} / 1000 \mathrm{~L}$, equivalent to $0.069 \mathrm{~kg} / \mathrm{ton}$ of feed). 
Danbury TC, Weeks CA, Chambers JP, Waterman-Pearson AE, Kestin SC. Self-selection of the analgesic drug carprofen by lame broiler chickens. Veterinary Record 2000;146:307-311.

Dawkins MS. Behavior as a tool in the assessment of animal welfare. Zoology 2003;106:383-387.

Dawkins MS, DonnellyyCA, Jones TA. Chicken welfare is influenced more by housing conditions than by stocking density. Nature 2004; 427:342344.

DucherG, CourteixD, MemeS, MagniC, VialaJF,BenhamouCL.Bone geometry in response to long-term tennis playing and its relationship with muscle volume: a quantitative magnetic resonance imaging study in tennis players. Bone 2005;37: 457-466.

Edwards Jr. HM, Elliot MA, Sooncharernying S. Effect of dietary calcium on tibialdyschondroplasia. Interaction with light, cholecalciferol, 1.25-dihydroxycholecalciferol, protein and synthetic zeolite. Poultry Science 1992;71:2041-2055.

Edwards Jr. HM. Theeffect of dietarycholecalciferol, 25-hydroxycholecalciferol and 1.25-dihydroxycholecalciferol on the development of tibialdyschondroplasia in broiler chickens in the absence and presence of disulfiram. Journal of Nutrition 1989; 119:647-652.

Elkin RG, Featherston WR, Rogler JC. Investigations of leg abnormalities in chicks consuming high tannin sorghum grain diets. Poultry Science $1978 ; 57: 757-762$

Graham JH, Freeman DC, Emlen JM. Antisymmetry, directional asymmetry and chaotic morphogenesis.Genetica 1993;89:121- 137.

Gonzales E, Macari M. Enfermidadesmetabólicas em frangos de corte. In: Berchieri Júnior A, Macari M. Doençasdas aves. Campinas: FACTA; 2000. p. 449-464.

Hall AL. The effect of stocking density on the welfare and behaviour of broiler chickens reared commercially. Animal Welfare 2001;10:23-40.

KestinSC, Knowles TG, Tinch AE, Gregory NG. Prevalence of leg weakness in broiler chickens and its relationship with genotype. The Veterinary Record 1992;131:190-194

KestinSC, Su G, Sorensen P. Different commercial broiler crosses have different susceptibilities to leg weakness. Poultry Science 1999;78:10851090

Kestin SC, Gordon S, Su G, Sorensen P. Relationships in broiler chickens between lameness, liveweight, growth rate and age. Veterinary Record 2001;148:195-197.

Knierim U, Van Dongen S, Forkman B, Tuyttens FAM, Spinka M, Campo $J \mathrm{~L}$, Weissengruber GE. Fluctuating asymmetry as an animal welfare indicator - A review of methodology and validity. Physiology \& Behavior 2007;92: 398-421.

Knowles TG, Kestin SC, Haslam SM, Brown SN, Green LE. Leg disorders in broiler chickens: prevalence, risk factors and preventio. PLOS ONE 2008;3e1545. Available from: http://dx.doi.org. doi:10.1371/journal. pone.0001545.

Leary RF,Allendorf FW. Fluctuating asymmetry as an indicator of stress: implications for conservation biology. Trends in Ecology and Evolution $1989 ; 4: 214-217$

McGeown D, Danbury TC, Waterman-Pearson AE, Kestin SC. Effect of carprofen on lameness in broiler chickens. Veterinary Record 1999;144:668-671.

Manning L, Chadd SA, Baines RN. Key health and welfare indicators for broiler production. World's Poultry Science Journal 2007; 63: 46-62.

Minitab ${ }^{\circledR}$ Statistical Software for Windows, 2007 [cited 2010 Feb]..Available from: http://www.minitab.com/products/minitab/.
Mckenzie JA, Clarke GM. Diazinon resistance, fluctuating asymmetry and fitness in the Australian sheep blowfly. Genetics 1988;77:385-394.

Mitchell RD, Edwards Jr. HM,McDaniel GR, Rowland GN. Dietary 1,25-dihydroxycholecalciferol has variableeffects on the incidences of leg abnormalities, plasma vitamin D metabolites, and vitamin D receptors in chickens divergently selected for tibialdyschondroplasia. Poultry Science 1997;76:338-345

Møller AP. Directional selection on directional asymmetry: testes size and secondary sexual characters in birds. Proceedings of the Royal Society London1994; B 258: 147-151.

NääsIA, Baracho MS, Salgado DD, Sonoda L, Carvalho VC, Moura DJ Paz ICLA. Broilers'toes asymmetry and walking ability assessment. EngenhariaAgrícola 2009;29:538-546.

Onyango EM, Hester PY, Stroshime R. Bone densitometry as an indicator of percentage tibia ash in broiler chicks fed varying dietary calcium and phosphorus levels. Poultry Science 2003; 82:1787-1791.

Rath NC, Huff WE, Bayyari GR, Balog JM. Cell death in avian tibialdyschondroplasia. Avian Disease 1998;42:72-79.

Ravindran V, Thomas DV, Thomas DG, Morel PCH. Performance and welfare of broilers as affected by stocking density and zinc bacitracin supplementation. Animal Science Journal 2006;77:110-116.

Reiter K, Kutritz B.Behaviour and leg weakness in different broiler breeds Archiv fur Geflugelkunde 2001;65:137-141

Rennie JS,Whitehead CC. Effectiveness of dietary 25- and 1-hydroxy cholecalciferol in combating tibialdyschondroplasia in broiler chickens. British Poultry Science 1996;37:413-421.

Skinner JT, Adams MH, Watkins SE, Waldroup PW. Effect of calcium and nonphytate phosphorus levels fed during 42 to 56 days of age on performance and bone strength of male broilers. Journal of Applied Poultry Research 1992 1(2):167-171.

Sorensen P, Su G, Kestin SG. Effects of age and stocking density on leg weakness in broiler chickens. Poultry Science 2000;79:864-870.

Tuyttens FAM. Measures of developmental instability as integrated a-posteriori indicators of farm animal welfare: a review. Animal Welfare 2003:12:535-40.

Van Valen L. A study of fluctuating asymmetry. Evolution 1962;16:125-142

Van Poucke E, Van Nuffel A, Van Dongen S, Sonck B, Lens L, Tuyttens FAM Experimental stress does not increase fluctuating asymmetry of broiler chickens at slaughter age. Poultry Science 2007;86:2110-2116.

Van Nuffel A, Tuyttens FAM, Van Dongen S, Talloen WE, Van Poucke E, Sonck B, Lens L. Fluctuating asymmetry in broiler chickens: A decision protocol for trait selection in seven measuring methods. Poultry Science 2007;86:2555-2568.

Waldensted TL. Nutritional factors of importance for optimal leg health in broilers: a review. Animal Feed and Technology 2006;126: 291-307.

Weary DM, Niel L, Flower CF, Fraser D. Identifying and preventing pain in animals.Appl. Animal Behaviour Science 2006;100:64-76.

Weeks CA, Danbury TD, Davies HC, Hunt P, KestinSC. The behavior of broiler chickens and its modification by lameness. Applied AnimalBehaviour Science 2000,67:111-125.

Whitehead CC, McCormack HA, McTier L, Fleming RH. High Vitamin $D$ requirements in broilers for bone quality and prevention of tibialdyschondroplasia and interactions with dietary calcium, available phosphorus and Vitamin A.BritishPoultry Science 2004;45:425-436.

Zhang B, Coon CN. The relations ships of various tibia bone measurements in hens. Poultry Science 1997;76:1698-1701. 